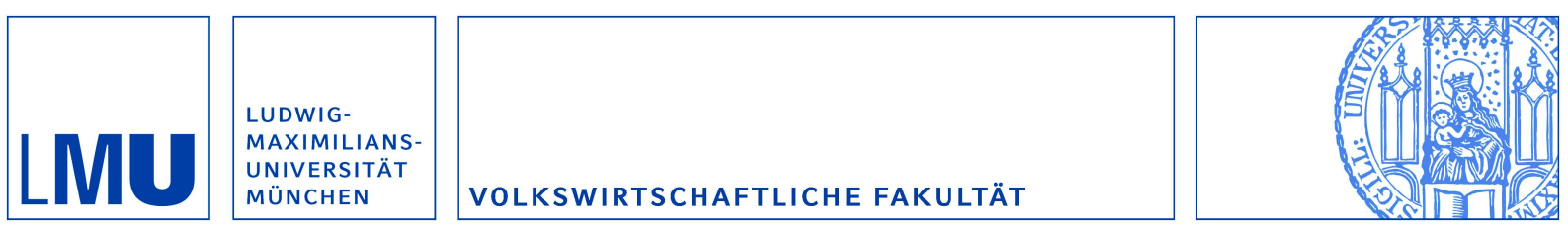

Haufler, Andreas und Maier, Ulf:

Regulatory competition in capital standards with selection effects among banks

Munich Discussion Paper No. 2016-5

Department of Economics

University of Munich

Volkswirtschaftliche Fakultät

Ludwig-Maximilians-Universitäł München

Online at https://doi.org/10.5282/ubm/epub.27700 


\title{
Regulatory competition in capital standards with selection effects among banks*
}

\author{
Andreas Haufler ${ }^{\dagger}$ \\ University of Munich and CESifo \\ Ulf Maier $\ddagger$ \\ University of Munich
}

March 2016

\begin{abstract}
Several countries have recently introduced national capital standards exceeding the internationally coordinated Basel III rules, thus suggesting a 'race to the top' in capital standards. We study regulatory competition when banks are heterogeneous and give loans to firms that produce output in an integrated market. In this setting capital requirements change the pool quality of banks in each country and inflict negative externalities on neighboring jurisdictions by shifting risks to foreign taxpayers and by reducing total credit supply and output. Non-cooperatively set capital standards are higher than coordinated ones when governments care equally about bank profits, taxpayers, and consumers.
\end{abstract}

Keywords: regulatory competition, capital requirements, bank heterogeneity JEL Classification: G28, F36, H73

*Paper presented at seminars and conferences in Bremen, Burnaby (Simon Fraser), Exeter, Glasgow (Strathclyde), Luxembourg, Munich, Oxford, Uppsala, Würzburg and Zurich. We thank conference participants, in particular Steve Bond, Pierre Boyer, Michael Devereux, Alan Morrison, Klaus Schmidt, Tim Schmidt-Eisenlohr and Michael Stimmelmayr for helpful comments. Financial support from the German Research Foundation (Grant No. HA 3195/9-1) is gratefully acknowledged.

${ }^{\dagger}$ Corresponding author. Seminar for Economic Policy, Akademiestr. 1/II, D-80799 Munich, Germany. Phone: +49-89-2180-3858, fax: +49-89-2180-6296, e-mail: Andreas.Haufler@econ.lmu.de

‡e-mail: Ulf.Maier@econ.lmu.de 


\section{Introduction}

The regulation of banks, and in particular the setting of capital adequacy standards, is arguably one of the most important policy issues in the aftermath of the financial crisis. In many countries large, commercial banks needed to be recapitalized with public funds in recent years. In several countries, such as Ireland or Iceland, the public bailout was so massive that it threatened the entire state of public finances. The new Basel III capital standards, which foresee the ratio of core (Tier 1) capital to risk-weighted assets to rise to 7 percent until 2019, are therefore widely believed to represent a critical step forward in ensuring more resilient banking sectors around the world. ${ }^{1}$ At the same time, the higher capital standards are also expected to lead to a consolidation of banking sectors, with smaller or weaker banks having to exit the market.

The financial sectors of many countries have grown dramatically in recent decades and represent an important source of value added, highly paid jobs, and - in good times tax revenue. ${ }^{2}$ Therefore, an important concern in policy discussions is that the national setting of higher capital adequacy standards will not distort international competition between the banking sectors of different countries, and maintain a 'level playing field'. Interestingly, however, it is by no means clear whether individual countries, which may be tempted to pursue beggar-thy-neighbor policies, have an incentive to set their national capital standards above or below that of neighboring jurisdictions. ${ }^{3}$

On the one hand is the conventional concern that maintaining low capital adequacy rules reduces the cost of doing business for domestic banks, thus securing an 'unfair' ad-

\footnotetext{
${ }^{1}$ Thus Mervyn King, then Governor of the Bank of England, noted in October 2010 that "the broad answer to the problem [of finding adequate regulatory tools] is likely to be remarkably simple. Banks should be financed much more heavily by equity rather than short-term debt" (www.bankofengland.co.uk/publications/Documents/speeches/2010/speech455.pdf). Similarly, Timothy Geithner, then U.S. Secretary of the Treasury, emphasized in February 2010 that "first, we are going to make sure that financial firms hold a lot more capital than they did before the crisis" (www.treasury.gov/press-center/press-releases/Pages/tg808.aspx).

${ }^{2}$ Auerbach et al. (2010, Figure 9.5) document the increasing fiscal importance of the financial sector in the United States and the United Kingdom. In both countries, corporate tax revenues from financial corporations made up more than $25 \%$ of total corporate tax revenues in 2003, before the financial crisis.

${ }^{3}$ This is very different from the issue of tax harmonization, for example, where the concern is almost exclusively about a downward competition of tax rates. See Keen and Konrad (2013) for a recent survey of this literature.
} 
vantage in the international competition for bank customers. This concern is echoed in the entire existing literature on the subject (to be discussed below), which unanimously holds that national capital standards will be set too lax in the process of international policy competition, and a 'race to the bottom' will therefore result.

At the same time, many countries have enacted capital standards that substantially exceed the internationally coordinated Basel III rules. Switzerland, for example, introduced a core capital ratio of $10 \%$ for its largest banks, well above the Basel III standards, and it did so earlier than implied by the Basel schedule. Similarly, the United States demands a leverage ratio of core capital to unweighted assets equal to $5 \%$, significantly above the Basel III standard of $3 \%$, from its largest and systemically relevant banks (Board of Governors of the Federal Reserve System, 2014). In the European Union, British plans to impose national capital standards above the Basel III standards met with stern resistance from most EU partners. ${ }^{4}$ The final compromise was that the United Kingdom was allowed to implement national capital standards ahead of the Basel III schedule, but that it would not exceed the capital standards in other EU member states.

In sum, the policy experience in many developed countries shows that the national setting of capital standards seems to be more aptly characterized by a 'race to the top', rather than by the conventional 'race to the bottom'. The warning of a 'race to the top' is also explicitly used by the European Commission to motivate why capital standards in EU member states must be strictly harmonized at the level of the Basel III accord: "It is uncertain what the potential impact in terms of costs and growth would be in case of higher capital requirements in one or more Member States, potentially expanded through a 'race to the top' mechanism across the EU" (European Commission, 2011, p. 10).

Despite the direct policy relevance indicated by these developments, we are not aware of any contribution to the literature that explains why countries have an incentive to set national capital standards above the internationally coordinated levels. The present paper aims to fill this gap. Our model of regulatory competition in capital standards introduces two new features that together are able to explain why governments may set "excessively strict" capital standards.

First, our model allows for banks that are heterogeneous in their monitoring ability,

\footnotetext{
${ }^{4}$ See "European Leaders to weigh new capital requirements for banks", The New York Times, May $1,2012$.
} 
and hence in their probability of failure. When individual banks are unable to signal their quality themselves, higher capital standards act as a signal of average quality in the national banking sector. This is because higher capital standards drive the weakest banks from the market and thus improve the pool quality of the remaining banks. This selection effect of capital standards benefits the remaining banks, because loan-taking firms anticipate the increase in average bank quality and are willing to pay higher loan rates in exchange for the added security. Moreover a higher average bank quality also benefits taxpayers, who have to (partly) come up for the losses of failing banks by means of a deposit insurance scheme.

A second distinguishing feature of our model is that it incorporates the repercussions that changes in the availability and the price of credit have on the real economy. Our model incorporates competitive firms that use bank credit to produce output for an integrated market. Higher capital standards in one country will then reduce aggregate output, and accordingly consumer surplus, in both countries. Hence, through the integrated output market, tougher capital standards in each country impose a basic negative externality on consumers in the neighboring jurisdiction.

Overall, we thus consider governments that incorporate taxpayers and consumers in their welfare function, in addition to the profits of the banking sector. The main result of our analysis is that when governments care equally about bank profits, consumers and taxpayers, the non-cooperative setting of capital standards will lead to higher levels of capital regulation than is optimal from a global welfare perspective. Intuitively, higher capital standards in the home country shift some of the loan volume to the neighboring country, raising the banking sector's profits there. These effects are offset, however, by the negative externality of higher capital standards on the foreign country's consumers, which operates through the integrated output market. At the same time, the average quality of bank loans increases in the more regulated country, but decreases in the foreign country, where weak banks are drawn into the market by the higher demand for loans. This leads to a shifting of risks to foreign taxpayers, whose expected losses rise due to both the higher loan volume and the lower average quality of banks in their country. In sum, the externalities of stricter capital regulation in one country on the foreign country's welfare are therefore negative, implying a 'race to the top' when capital standards are set non-cooperatively by the two countries.

In an extension of our benchmark model we permit individual banks to signal their quality by financing their loans with a share of equity that is (sufficiently) above the 
minimum capital standard imposed by their country of residence. In equilibrium, this signal will be chosen by all banks that exceed a critical quality level. In this extended setting, national capital requirements maintain their role of forcing the weakest banks to exit the market and of improving the pool quality of the remaining banks. Moreover, by increasing the costs of operating in the low quality pool, a higher minimum capital requirement will induce more firms to opt into the high quality pool, and raise its capital standards accordingly. Hence, minimum capital requirement now have a twofold, positive effect on the share of equity financing in the national banking sector, protecting taxpayers more effectively from the risks of bank failures.

Our analysis is related to several strands in the existing literature. A first set of papers analyzes the effects of capital regulation on financial institutions (Rochet, 1992; Hellman et al., 2000; Repullo, 2004). This literature stresses that capital regulation increases the risk buffer of banks and curbs risky behaviour. In one of the few contributions that incorporate bank heterogeneity, Morrison and White (2005) show that capital regulation also serves to address adverse selection problems in the banking sector. Kopecky and VanHoose (2006) also model heterogeneous monitoring costs of firms and show that capital regulation is likely to increase the overall loan quality in this framework. All these models stress that capital regulation is costly for banks. ${ }^{5}$

Most directly related to our analysis is the small literature on regulatory competition in the banking sector. Sinn $(1997,2003)$ models the competition in regulatory standards as an application of the classical lemons problem (Akerlof, 1970), arguing that consumers are unable to discriminate between different levels of regulatory quality. Acharya (2003) introduces competition between bank regulators that choose both the level of capital requirements and the bailout policy when banks become insolvent. Dell'Ariccia and Marquez (2006) model regulators that choose national capital requirements by trading off the aggregate level of bank profits against the benefits of financial stability. All these papers arrive at the conclusion that national capital standards are set inefficiently low from a global welfare perspective. Also, none of these papers incorporates bank heterogeneity, nor firms that use bank loans to produce real output.

A reputation effect that benefits banks is present in the model of Morrison and White (2009). In their framework, however, the beneficial reputation effect arises from the

\footnotetext{
${ }^{5}$ An opposing view is taken by Admati and Hellwig (2013), who argue that higher capital requirements reduce the risk premia incorporated in banks' equity capital, and therefore need not raise the banks' overall financing costs.
} 
quality of the regulator, for which capital requirements act as a substitute. Hence high capital standards are associated with a negative signal, contrary to our approach. Moreover, Morrison and White (2009) do not model international competition between banks and their focus is on the question of whether a uniform regulatory standard is beneficial for countries that differ with respect to the quality of their national regulator.

The heterogeneity of banks that we incorporate in this paper has become an important topic in the recent international trade literature. Buch et al. (2011) show a close empirical link between size, productivity and international activity in the banking sector that is similar to the well-established patterns for the manufacturing sector. Niepmann (2013) introduces heterogeneous monitoring ability of banks in a general equilibrium trade model where banks of different quality and size sort into cross-border lending and foreign direct investment. Finally, the recent public economics literature has stressed the qualitative similarities between regulation and taxation of the financial sector (Keen, 2011). It has also provided first empirical results showing that recent bank levies have been effective in increasing the equity-to-asset ratio of European banks (Devereux et al., 2013).

This paper is set up as follows. Section 2 presents our benchmark model. Section 3 analyzes the nationally optimal regulation policy. Section 4 turns to the central issue of whether decentralized capital standards are set higher or lower than is globally optimal. Section 5 analyzes three extensions of our benchmark model, introducing in

turn foreign ownership of banks, asymmetries between countries and quality signalling by individual banks. Section 6 concludes.

\section{The model}

\subsection{Banks}

We consider a region of two countries $i \in\{1,2\}$, which are identical in all respects. Banks in each country extend loans to firms in an integrated regional market. In each country multiple, heterogeneous banks operate under the authority of a national regulator who imposes capital requirements $k_{i}$ for all national banks. The number of active banks in each country and the volume of loans distributed by each bank are endogenous. Banks differ exogenously in their monitoring skills, which determine the quality $q$ of 
the individual bank. ${ }^{6}$ We assume that the variable $q$ is distributed uniformly in the interval $[0,1]$ and it corresponds to the likelihood that the investment financed by the individual bank's loan is successful. Thus, our model effectively assumes that the bank's monitoring quality is the critical determinant in the success of firms.

There are several ways in which the quality of a bank can improve the payoff to borrowers during the production process. First, due to their repeated interaction with different customers, banks acquire a knowledge that is complementary to that of firms (see Boot and Thakor, 2000). In this sense, $q$ can be interpreted as the general and sector-specific expertise of an individual bank, which directly affects the probability of successful production. Second, especially smaller and less mature firms derive substantial benefits from having long and stable relationships to banks, as they can more flexibly draw on existing lines of credit (Ivashina and Scharfstein, 2010), or receive favorable credit terms for new loans (Bolton et al., 2013). With such 'relationship lending', the probability of successful production will again be a function of bank quality, when $q$ is interpreted as the ability of banks to monitor projects and thus manage the liquidity pools of their portfolios. ${ }^{7}$ Given these reasons for why a firm's success rate is positively correlated with its bank's monitoring quality, our assumption that this correlation is perfect merely serves to simplify the analysis.

Each bank can fund itself either through equity capital or through external funds, which we take to be saving deposits of individuals. In line with with common practice in virtually all developed countries, we assume that the savings deposits are fully insured by the government of the country in which the bank is located. ${ }^{8}$ Hence, and importantly for our model, the (expected) costs of bank failures are partly borne by the taxpayers of the bank's residence country. Being fully insured against failure, depositors demand a competitive return on their savings, which we normalize to unity. In contrast, equity

\footnotetext{
${ }^{6}$ See Morrison and White (2005) for a similar assumption. The bank's monitoring decision could also be endogenized by assuming that banks differ exogenously in their monitoring costs and each bank chooses the degree of monitoring optimally, given its cost. Endogenizing $q$ would, however, complicate our analysis significantly, without changing its qualitative results.

${ }^{7}$ See Inderst (2013) for a recent analysis where the expected payoff of projects depends on the ability of banks to roll over loans, and for examples of capital losses to firms when their bank fails or encounters liquidity problems.

${ }^{8}$ The main argument in favor of deposit insurance schemes is that they prevent bank-runs and thus stabilize the banking system. See Barth et al. (2006) for an overview of deposit insurance schemes around the world, and for a discussion of its benefits and costs.
} 
holders may demand a risk premium and the per-unit cost of equity is exogenously given by $\rho \geq 1 .^{9}$

Another critical assumption of our benchmark model is that individual banks are not able to signal their quality to firms. ${ }^{10}$ Hence, no bank will choose to hold costly equity capital in excess of the minimum level $k_{i}$ stipulated by the national regulator. At the same time, the capital adequacy ratio set by the government of country $i$ will, in ways that we specify in more detail below, determine the return that firms are willing to pay for a loan from a bank resident in country $i$. The expected profits of a bank located in country $i$ with quality $q$ that chooses to distribute a total number of $l$ loans are then given by

$$
\pi_{i}(q, l)=q\left[R_{i}-\left(1-k_{i}\right)\right] l-\rho k_{i} l-\frac{1}{2} b l^{2} \quad \forall i \in\{1,2\} .
$$

Here $R_{i}$ is the return per unit of the bank's loans, which depends on the capital standards set by the bank's home country $i$, but not on the individual quality of the bank. From this gross loan rate the bank must deduct the costs of savings deposits $\left(1-k_{i}\right)$, which are paid back by the bank only with its success probability $q$. The return on the bank loan is zero, if the borrowing firm's risky investment fails. In this case the bank will also go bankrupt and savers will be compensated by payments from the national deposit insurance fund. Total equity capital in the bank is $k_{i} l$ and equity holders have a fixed opportunity cost of $\rho$ per unit of capital invested. Finally, the quadratic cost term $(1 / 2) b l^{2}$ represents transaction costs that are rising more than proportionally when the bank's level of operation rises. This term therefore limits the scale of operations in each bank. ${ }^{11}$ All net profits, and all uncovered losses, accrue to equity holders as residual claimants.

We assume that all banks are small relative to the overall loan market and hence take $R_{i}$ as given when choosing $l .^{12}$ The optimal loan volume $l^{*}$ for each bank in country $i$

\footnotetext{
${ }^{9}$ Admati and Hellwig (2013) argue that the per-unit cost of equity should be endogenized, and it should fall when the capital requirement is increased. In our model, however, a higher capital requirement will always increase the bank's overall costs of funds, because a higher equity share reduces the value of implicit taxpayer subsidies. Therefore, ignoring the feedback effects of changes in $k_{i}$ on the per-unit cost of equity capital $\rho$ will not affect our results qualitatively.

${ }^{10}$ This assumption will be relaxed in Section 5.3, which introduces (imperfect) quality signalling by individual banks.

${ }^{11}$ See Acharya (2003) for a similar assumption.

${ }^{12}$ In Germany, for example, more than 2.200 banks are active in the market (Buch et al., 2011). Hence the share in the total loan market is small, even for the largest banks.
} 
is then given by

$$
l^{*}=\frac{q \phi_{i}-k_{i} \rho}{b} \quad \forall i
$$

where we have defined the short-hand notation

$$
\phi_{i} \equiv R_{i}-1+k_{i} \quad \forall i
$$

to indicate the return per unit of loans for each bank located in country $i$, net of the funding costs for savings deposits. This term therefore represents the expected increase in the cash flow of a bank in country $i$ when the success probability of its loan increases. It is clear from (2) that the loan volume of a bank is an increasing function of its quality $q$. Thus, a better bank is also larger in equilibrium. ${ }^{13}$ Moreover, the loan volume is an increasing function of the return $R_{i}$ and a decreasing function of the capital adequacy ratio $k_{i}$, both of which are specific to the country in which the bank is located.

Substituting (2) in (1) determines the optimized profits of a bank of quality $q$ in country $i$ :

$$
\pi_{i}^{*}(q)=\frac{\left(q \phi_{i}-k_{i} \rho\right)^{2}}{2 b} \quad \forall i
$$

The equilibrium number of banks in country $i$ is determined by the condition that the marginal bank, denoted by the cutoff quality level $\hat{q}_{i}$, receives zero expected profits from its operations:

$$
\pi_{i}\left(\hat{q}_{i}\right)=\hat{q}_{i} \phi_{i}-k_{i} \rho=0 \quad \forall i .
$$

Consequently, only banks with $q \geq \hat{q}_{i}$ will be active in the market. Equation (5) shows that capital standards in country $i$ directly affect the cutoff quality level $\hat{q}_{i}$ by increasing the cost of capital for all banks. As low-quality banks benefit most from limited liability and cheap deposit funding, they are hit hardest by an increase in capital standards. Without any capital requirements $\left(k_{i}=0\right)$, all banks will be active in the market $\left(\hat{q}_{i}=0\right)$. In contrast, full equity financing of banks $\left(k_{i}=1\right)$ results in $\hat{q}_{i}=\rho / R_{i}$. Hence, a necessary condition for a positive number of banks to stay in the market even with full equity financing is that the cost of equity $\rho$ is lower than the equilibrium return on loans, $R_{i}$. We make this assumption in the following.

It remains to determine the aggregate loan volume of all active banks in country $i$. We normalize the exogenously given number of potentially entering banks to unity. To

\footnotetext{
${ }^{13}$ This corresponds to the empirical evidence in Buch et al. (2011) that bank productivity and bank size are positively correlated. Productivity is measured either as labor productivity (assets/employees), or as the bank-level difference between average revenues and marginal costs.
} 
arrive at the aggregate loan volume, we integrate over the optimal loan volumes (2) of all active banks. This gives

$$
L_{i}=\int_{\hat{q}_{i}}^{1} l(q) d q=\frac{\left(1-\hat{q}_{i}\right)\left(\phi_{i}-k_{i} \rho\right)}{2 b}=\frac{\left(1-\hat{q}_{i}\right)^{2} \phi_{i}}{2 b} \quad \forall i .
$$

Here $\left(1-\hat{q}_{i}\right)$ is the measure of active banks in country $i$, whereas $\left(\phi_{i}-k_{i} \rho\right) / 2 b$ gives the average loan volume per active bank. ${ }^{14}$ The second step in (6) then uses (5) to simplify the resulting expression.

\subsection{Firms and consumers}

One of the features of our model is that we explicitly incorporate firms that use bank loans to produce consumer goods. In the following sections this will allow us to study the welfare effects of capital standards on banks, taxpayers and consumers.

We assume that there is a large number of identical, potential producers in an integrated final goods market, which do not have any private sources of funds. The potential producers compete for credit in the loan market. Each firm that enters the market in equilibrium demands one unit of credit to produce one unit of output. Total output in the integrated market therefore depends on the expected number of successful loans from banks in both countries. Denoting the expected output produced with loans from banks located in country $i$ by $y_{i}$, total output is ${ }^{15}$

$$
y \equiv y_{i}+y_{j}=\int_{\hat{q}_{i}}^{1} q l(q) d q+\int_{\hat{q}_{j}}^{1} q l(q) d q=L_{i}\left(\frac{2+\hat{q}_{i}}{3}\right)+L_{j}\left(\frac{2+\hat{q_{j}}}{3}\right) \quad \forall i \neq j .
$$

Next we determine the loan rate that firms are willing to pay to banks from each country $i$ in the competitive equilibrium. All potential entrants in the final goods sector have to incur a uniform fixed cost $c$ for their projects. Further, as firms can not

\footnotetext{
${ }^{14}$ Using eq. (2) shows that this term is the unweighted average of the loan volume chosen by the best bank (with $q=1$ ), and the loan volume of the marginal entering bank with $\hat{q}$, which is zero.

${ }^{15}$ Note from (7) that at least two thirds of all loans will lead to successful production, even in the absence of any capital requirements (i.e., for $\hat{q}=0$ ). This follows from our assumption of a uniform distribution of bank qualities and from the fact that high-quality banks supply more loans [see eq. (2)]. The expected success rate increases further, when capital requirements drive the worst banks from the market and $\hat{q}>0$.
} 
observe the quality of the contracting bank, they have to form expectations about the average quality of loans distributed by all active banks that reside in a specific country. We denote this expected success rate of loans originating from banks in country $i$ by $q_{i}^{e}$. If the investment is successful, the firm sells its product in the integrated market for the homogeneous consumer good. This output market is characterized by the inverse demand function $P=A-y$, where $A$ measures the size of the integrated market. A firm will not repay the loan if its project fails, but the fixed cost $c$ has been incurred nevertheless. Thus, allowing for free entry of firms into the output market, the zero profit condition for entering, risk-neutral firms implies

$$
q_{i}^{e}\left(P-R_{i}\right)=c \quad \forall i .
$$

Since producing firms are identical, they also make zero expected profits in the aggregate. Effectively, all expected profits are transferred to banks via the loan rate $R_{i}$.

To derive the equilibrium loan rate for banks in each country, $R_{i}$, we rearrange (8) and substitute the inverse demand function $P=A-y$. This gives:

$$
R_{i}=A-\frac{c}{q_{i}^{e}}-y=A-\frac{3 c}{2+\hat{q}_{i}}-y \quad \forall i
$$

In the second step of eq. (9) we have assumed that firms rationally anticipate the average success rate of loans from banks in country $i$, which is $q_{i}^{e}=\left(2+\hat{q}_{i}\right) / 3$ from $(7)$. Thus the loan price is decreasing in total output and in the amount of fixed costs $c$. Moreover, (9) shows that loan rates are country-specific and depend positively on the expected quality of the banking sector in country $i$. A higher expected quality of the banking sector in country $i$ reduces each firm's probability of failure and thus raises its willingness to pay for the loan. Hence, national capital requirements $k_{i}$ act as a selection mechanism by affecting the pool quality of national banks, which in turn determines the price that borrowers are willing to pay for a bank loan emanating from country $i$. Consequently the price of bank loans differs systematically between the two countries whenever their capital requirements differ, with bank loans from the country with the higher capital requirement receiving a higher return.

\subsection{Market equilibrium and welfare}

To derive the market equilibrium, we substitute eq. (9) into (5) and, together with (2), into (7). This yields a system of three simultaneous equations:

$$
\hat{q}_{1}\left[A-\frac{3 c}{2+\hat{q}_{1}}-y-1+k_{1}\right]=\rho k_{1},
$$




$$
\begin{aligned}
& \hat{q}_{2}\left[A-\frac{3 c}{2+\hat{q}_{2}}-y-1+k_{2}\right]=\rho k_{2}, \\
y=y_{1}+y_{2}= & \frac{1}{b} \int_{\hat{q}_{1}}^{1}\left[q^{2}\left(A-y-1+k_{1}\right)-q k_{1} \rho-q^{2}\left(\frac{3 c}{2+\hat{q}_{1}}\right)\right] d q \\
+ & \frac{1}{b} \int_{\hat{q}_{2}}^{1}\left[q^{2}\left(A-y-1+k_{2}\right)-q k_{2} \rho-q^{2}\left(\frac{3 c}{2+\hat{q}_{2}}\right)\right] d q .
\end{aligned}
$$

Equations (10a)-(10c) jointly determine the cutoff qualities of banks, $\hat{q}_{1}$ and $\hat{q}_{2}$, and the aggregate output level $y$, all as functions of the capital requirements $k_{1}$ and $k_{2}$ imposed by the two countries. These core variables then determine the total level of loans from each country from (6) and the country-specific loan rate from (9).

We consider a national regulator in each country who sets capital requirements so as to maximize national welfare. Welfare in country $i$ is taken to be a weighted sum of bank profits $\Pi_{i}$, tax revenue $T_{i}$ and consumer surplus $S$ :

$$
W_{i}=\alpha \Pi_{i}+\beta T_{i}+\gamma \frac{S}{2}, \quad \alpha, \beta, \gamma \geq 0 .
$$

Here $\Pi_{i}$ refers to the aggregate profits of all banks of country $i$ that are active in the regional market. In addition, the regulator considers the expected costs to resident taxpayers when banks fail and depositors must be compensated for their losses through the deposit insurance fund. Hence $T_{i}$ will always be negative. Finally, by affecting the supply of loans, capital standards also affect aggregate output and hence consumer surplus. Since the output market is regionally integrated, and the model is symmetric, we allocate one half of the total consumer surplus $S$ in the integrated market to each of the two countries.

These components of national welfare can be directly calculated from the equilibrium in the loan market. Total profits in the banking sector of country $i$ are given by aggregating (4) over all active banks. This yields

$$
\Pi_{i}=\int_{\hat{q}_{i}}^{1} \frac{\left(q \phi-k_{i} \rho\right)^{2}}{2 b} d q=\frac{\left(1-\hat{q}_{i}\right) \phi_{i} L_{i}}{3}=\frac{6 b y_{i}^{2}}{\left(2+\hat{q}_{i}\right)^{2}\left(1-\hat{q}_{i}\right)} \quad \forall i,
$$

where we have used (6) and (7) to express banking sector profits in country $i$ as a function of output with loans from country $i$ and of the cutoff quality of banks in $i$. The expected losses borne by taxpayers in country $i$ arise from the deposit insurance scheme. ${ }^{16}$ These losses are determined by the share of deposit financing, the aggregate

\footnotetext{
${ }^{16}$ Our analysis abstracts from insurance funds paid by the banking sector. Several countries, such
} 
loan volume, and the average failure probability of country $i$ 's banks. Moreover, we abstract from international contagion effects and assume that the losses from failed banks arise only in the country in which the bank is located. ${ }^{17}$ Aggregating and using (6) and (7) in the second step gives

$$
T_{i}=\frac{-\left(1-k_{i}\right)}{b} \int_{\hat{q}_{i}}^{1}(1-q)\left(q \phi_{i}-k_{i} \rho\right) d q=\frac{-\left(1-k_{i}\right)\left(1-\hat{q}_{i}\right) L_{i}}{3}=\frac{-\left(1-k_{i}\right)\left(1-\hat{q}_{i}\right) y_{i}}{\left(2+\hat{q}_{i}\right)}
$$

Finally, by affecting aggregate output, capital standards also affect the consumer surplus in the integrated market. Total consumer surplus in the region is

$$
S=\frac{1}{2}(A-P) y=\frac{y^{2}}{2}
$$

which is shared equally in equilibrium between the two symmetric countries.

From (12)-(14) we can thus determine the effects of capital requirements on national and regional welfare, as well as its components.

\section{$3 \quad$ Nationally optimal capital standards}

\subsection{Equilibrium in the loan market}

In this section we analyze the effects of capital requirements that are set noncooperatively by the two countries. Thus we are looking for a symmetric Nash equilibrium in the national policy instruments $k_{i}$ when each country maximizes the welfare of its citizens, as given in (11). Appendix A.1 derives the changes in the endogenous variables $\hat{q}_{i}, \hat{q}_{j}, y_{i}$ and $y_{j}$ in response to a unilateral increase in country $i$ 's capital as Germany, are currently building up special funds financed by compulsory bank levies, in order to make the banking sector participate in the costs of bank restructurings. The size of these insurance funds is (still) small, however. In Germany, for example, the volume of this 'restructuring fund' is only around 2 billion Euro after four years of collecting bank levies, far below its target value. From 2016 onwards, national restructuring funds in the European Union will be transferred into an EU-wide resolution fund, but this is built up only gradually and with a moderate overall target volume.

${ }^{17}$ See Niepmann and Schmidt-Eisenlohr (2013) and Beck and Wagner (2013) for analyses of international regulatory coordination when bank failures in one country have adverse effects on banks in the other country. 
requirement $k_{i}($ where $i \neq j)$. These are given by ${ }^{18}$

$$
\begin{gathered}
\frac{\partial \hat{q}_{i}}{\partial k_{i}}=\frac{(\rho-\hat{q})\left[6 b(\phi+\tilde{c} \hat{q})+2 \phi\left(1-\hat{q}^{3}\right)\right]+\rho(\phi+\tilde{c} \hat{q})(2+\hat{q})(1-\hat{q})^{2}}{2(\phi+\tilde{c} \hat{q}) \Omega}>0, \\
\frac{\partial \hat{q}_{j}}{\partial k_{i}}=\frac{\hat{q}(1-\hat{q}) \kappa}{2(\phi+\tilde{c} \hat{q}) \Omega}, \\
\frac{\partial y_{i}}{\partial k_{i}}=\frac{(1-\hat{q})\left[6 b(\phi+\tilde{c} \hat{q})+2 \phi\left(1-\hat{q}^{3}\right)\right] \kappa}{12 b(\phi+\tilde{c} \hat{q}) \Omega}, \\
\frac{\partial y_{j}}{\partial k_{i}}=\frac{-2 \phi(1-\hat{q})\left(1-\hat{q}^{3}\right) \kappa}{12 b(\phi+\tilde{c} \hat{q}) \Omega}, \quad \frac{\partial y}{\partial k_{i}}=\frac{(1-\hat{q}) \kappa}{2 \Omega},
\end{gathered}
$$

where we have introduced the short-hand notations

$$
\begin{gathered}
\Omega \equiv 3 b(\phi+\hat{q} \tilde{c})+2 \phi\left(1-\hat{q}^{3}\right)>0, \\
\tilde{c} \equiv \frac{3 c}{(2+\hat{q})^{2}}
\end{gathered}
$$

and

$$
\kappa=\underbrace{-\phi[3(\rho-1)(1+\hat{q})+(1+2 \hat{q})(1-\hat{q})]}_{\text {cost ef fect }}+\underbrace{\tilde{c}(1-\hat{q})(2+\hat{q}) \rho}_{\text {selection effect }}<>0
$$

Equation (15) shows that an increase in country $i$ 's capital requirement unambiguously raises the quality of the cutoff bank in this country, $\hat{q}_{i}$. This is due to both the higher cost of equity in comparison to savings deposits $(\rho-1)$, and to the reduced volume of implicit taxpayer subsidies as a consequence of the higher equity ratio. Hence, by raising the cost of finance for all banks, capital requirements drive the weakest banks in country $i$ from the market. ${ }^{19}$

The remaining effects in (16)-(18) all depend on the size of $\kappa$, as given in (21). It is thus critical for our analysis to discuss the effects summarized by $\kappa$ in detail. As shown in (21), the effect of a higher capital requirement on the total level of performing loans can be decomposed into two parts. The first term is unambiguously negative, as capital standards raise the costs of refinancing for all banks. We label this the cost effect of higher capital standards. The second term involving $\tilde{c}$ [see eq. (20)] is, however, positive. This captures the positive effect of higher capital requirements on the pool quality of banks in country $i$. The rise in $\hat{q}_{i}$ induced by a higher capital requirement [see eq. (15)]

\footnotetext{
${ }^{18}$ To save on notation we omit country subscripts in the following when no confusion is possible, invoking the symmetry of our model.

${ }^{19}$ This effect is thus very similar to models where production taxes or subsidies affect the market entry decision of firms with heterogeneous production costs (see e.g. Chor, 2009).
} 
results in a higher loan rate that firms are willing to pay for loans from banks based in country $i$, as they face a lower probability of losing their fixed cost $c$. In the following we will refer to this effect as the selection effect of capital standards. In sum, we can therefore not $\operatorname{sign} \kappa$, in general.

If $\kappa<0$ the cost effect of higher capital standards in country $i$ dominates. In this case, the higher willingness to pay for loans from the improved bank pool in country $i$ is not sufficient to offset the higher funding costs of these banks. Consequently, banks in country $i$ will distribute fewer loans in the aggregate, resulting in less output being produced [see eq. (17)]. Due to the fall in output, the output price $P$ rises and competitive firms are willing to pay a higher loan rate to banks from country $j$. This higher profitability will draw additional banks in country $j$ into the market, thus lowering $\hat{q}_{j}$ [eq. (16)]. Moreover, the aggregate loan volume in country $j$ will also rise, and with it the output $y_{j}$ generated from these loans [eq.(18)]. Hence a unilateral increase in country $i$ 's capital requirement shifts business from banks in country $i$ to banks in country $j$. This is the core reason why existing models of cross-country competition in capital standards, which focus on aggregate bank profits as the main component of national welfare (Sinn, 1997; Dell'Ariccia and Marquez, 2006) predict a 'race to the bottom' when capital standards are endogenized.

In our model it is also possible, however, that the selection effect of a higher capital standard dominates and $\kappa>0$ holds in (21). In this case, the effects of a rise in $k_{i}$ on the loan volumes of countries $i$ and $j$ and on the critical bank quality in country $j$ are all reversed. In this case, a higher capital standard in country $i$ will boost the aggregate loan supply of banks in country $i$, as the remaining banks receive a higher loan rate $R_{i}$ on account of the higher pool quality of banks in country $i$. If $\kappa>0$, this increase in the loan volume of higher-quality banks dominates the effect that arises from the reduced number of active banks in country $i$. The expansion of loans from country $i$ will then reduce the profitability of banks in country $j$, raising $\hat{q}_{j}$ and reducing $y_{j}$.

The introduction of a small capital requirement in country $i$ is illustrated in Figure 1. Eq. (6), together with (7) yields an inverse supply function $R_{S}\left(y_{i}\right)$ that describes the loan rate in country $i$ as a positive function of $y_{i}$ when $y_{j}$ is held constant. At the same time, $P=A-\bar{y}_{j}-y_{i}$ gives the price that competitive firms achieve in the output market, as a function of country $i$ 's volume of successful loans. From this, the demand for loans from banks in country $i, R_{D}\left(y_{i}\right)$, can be derived as a parallel shift of the demand function in the output market. The vertical intercept of this shift is 
Figure 1: The effects of a small capital requirement in country $i$
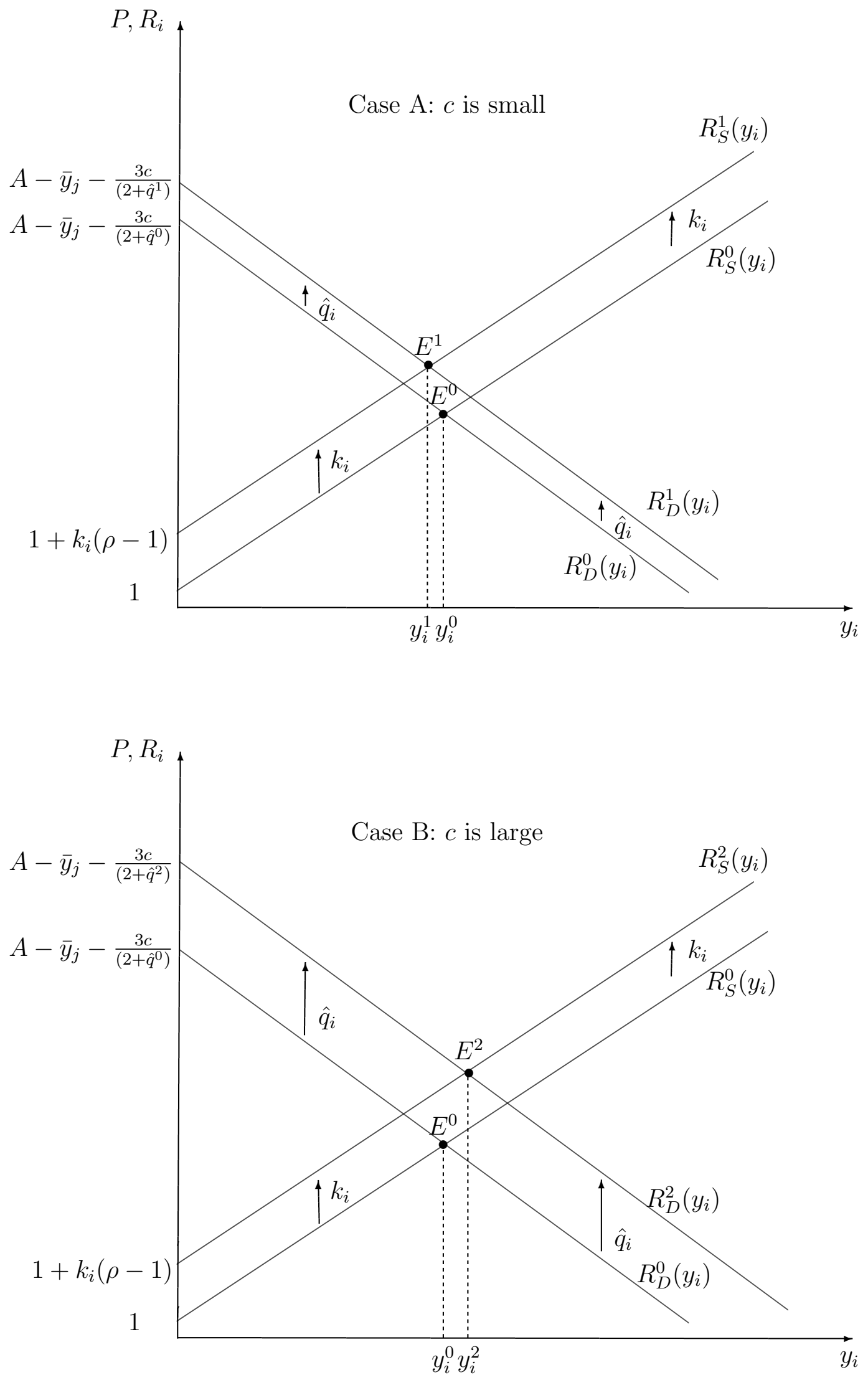
determined by the firms' fixed investment cost $c$ and the average success probability $\hat{q}_{i}$ [see eq. (9)].

In the absence of any capital requirements, the loan supply curve for country $i$ 's banks, $R_{S}^{0}$ starts at per-unit refinancing costs of unity. This represents the case of pure deposit finance. A small capital requirement $k_{i}$ shifts the loan supply curve upward (cost effect). The associated increase in the cutoff quality of country $i$ 's banks also leads to a parallel upward shift of the initial loan demand demand curve $R_{D}^{0}$, however, by lowering the firms' probability of losing their fixed costs (selection effect). In Case A, given in the upper panel of Figure 1, the fixed cost $c$ is small and the shift in the loan supply curve dominates the shift in the loan demand curve. As a result the equilibrium shifts from $E^{0}$ to $E^{1}$ and the volume of successful loans given by country $i$ 's banks is reduced from $y_{i}^{0}$ to $y_{i}^{1}$. In Case B, however, shown in the lower panel of the figure, the firms fixed costs $c$ are sufficiently large so that the upward shift in the loan demand curve to $R_{D}^{2}$ dominates the shift in the loan supply curve. Hence the equilibrium shifts from $E^{0}$ to $E^{2}$, resulting in an increase in successful loans by country $i$ 's banks from $y_{i}^{0}$ to $y_{i}^{2}$.

\subsection{Welfare effects of capital standards}

In a second step, we use the effects on the loan market equilibrium variables, as given in (15)-(18), to determine the effects of the capital standard $k_{i}$ on country $i$ 's welfare. Differentiating (11) and (12)-(14), we get

$$
\frac{\partial W_{i}}{\partial k_{i}}=\alpha \frac{\partial \Pi_{i}}{\partial k_{i}}+\beta \frac{\partial T_{i}}{\partial k_{i}}+\frac{\gamma}{2} \frac{\partial S}{\partial k_{i}},
$$

where

$$
\begin{gathered}
\frac{\partial \Pi_{i}}{\partial k_{i}}=\frac{18 b y_{i}^{2} \hat{q}_{i}}{\left(1-\hat{q}_{i}\right)^{2}\left(2+\hat{q}_{i}\right)^{3}} \frac{\partial \hat{q}_{i}}{\partial k_{i}}+\frac{12 b y_{i}}{\left(1-\hat{q}_{i}\right)\left(2+\hat{q}_{i}\right)^{2}} \frac{\partial y_{i}}{\partial k_{i}}, \\
\frac{\partial T_{i}}{\partial k_{i}}=\frac{\left(1-\hat{q}_{i}\right) y_{i}}{\left(2+\hat{q}_{i}\right)}+\frac{3\left(1-k_{i}\right) y_{i}}{\left(2+\hat{q}_{i}\right)^{2}} \frac{\partial \hat{q}_{i}}{\partial k_{i}}-\frac{\left(1-k_{i}\right)\left(1-\hat{q}_{i}\right)}{\left(2+\hat{q}_{i}\right)} \frac{\partial y_{i}}{\partial k_{i}}, \\
\frac{1}{2} \frac{\partial S}{\partial k_{i}}=y_{i} \frac{\partial y_{i}}{\partial k_{i}} .
\end{gathered}
$$

We first evaluate equations $(22 \mathrm{a})-(22 \mathrm{c})$ at an initial capital standard of $k_{i}=0$. In other words, we ask how welfare in country $i$ is affected by the introduction of a small capital standard. Note that an initial capital standard of $k_{i}=0$ implies $\hat{q}_{i}=0$ from (5). Turning first to the effects on the profits of country $i$ 's banking sector in (22a), the 
first term in this expression vanishes when $\hat{q}_{i}=0$ initially. Hence the effects on bank profits are exclusively determined by the change in the aggregate level of (successful) loans, as given by the second term. Similarly, the change in the volume of successful loans is also critical in determining the change in consumer surplus in the integrated market, as given in $(22 \mathrm{c})$.

The effects on tax revenues in (22b) are threefold. The first effect gives the direct, positive effect on tax collections (i.e. a reduction in expected subsidy payments) by decreasing the bank's reliance on deposits that are backed by a tax-financed insurance mechanism. Moreover, increasing the critical bank quality $\hat{q}_{i}$, and hence raising the average success rate of loans, additionally reduces the expected burden on taxpayers by the second effect. The sign of the third effect is ambiguous, however, as it will depend on the change in the aggregate volume of loans offered by banks in country $i$, and hence on the sign of $\kappa$.

In Appendix A.2 we derive the conditions under which (22a)-(22c) are all positive when evaluated at $k_{i}=0$ initially, and the introduction of a small capital standard strictly increases welfare in country $i$. These conditions are given by

$$
\begin{gathered}
\frac{3(2 \rho-1) c}{3 \rho-2}>(A-1), \\
{\left[\frac{15}{8}+\frac{1}{4 b}\right] c<(A-1) .}
\end{gathered}
$$

The inequality in (23a) is just the condition for $\kappa$ to be positive at $k=0$. Effectively, this requires that the firms' fixed investment costs $c$ must be sufficiently large, relative to the market size parameter $A$, which determines the profit margin of banks. If condition (23a) is fulfilled, the selection effect of capital standards dominates the cost effect when both are evaluated at an initial capital adequacy ratio of zero. Inequality (23b) states, in contrast, that the firms' fixed cost, and hence the induced expansion of bank loans is not so large as to overcompensate the positive first two effects of a small capital standard in the tax revenue expression $(22 \mathrm{~b}) .{ }^{20}$ We summarize these results in:

Proposition 1 (i) When firms' fixed production costs are sufficiently high, relative to the size of the output market [condition (23a) holds], then introducing a small capital standard $k_{i}>0$ raises the aggregate profits of country $i$ 's banking sector.

(ii) If, in addition, the firms' fixed costs c are not overly high, relative to market size

\footnotetext{
${ }^{20}$ Note that conditions (23a) and (23b) are not mutually exclusive. For example, if $\rho=1$ and $b=2$, both conditions are simultaneously fulfilled when $3 c>A-1>2 c$.
} 
[condition (23b) holds], then introducing a small capital standard $k_{i}>0$ benefits banks, consumers and taxpayers in country $i$ simultaneously and country $i$ 's welfare is improved for any combination of $\alpha, \beta, \gamma \geq 0$.

Our model thus shows that in the presence of selection effects, introducing capital standards may be unanimously approved by all agents in a country, even if the regulation is imposed unilaterally. In particular, introducing a small capital standard may be in the overall interest of the country's banking sector when the latter is heterogeneous. By raising the costs of doing business, the capital standard drives the least productive (most risky) banks from the market. High-quality banks will then benefit from the market exit of low-quality banks via a higher loan rate. When firms value the increase in the pool quality of banks sufficiently, as measured in our model by their fixed costs of production $c$, then the higher profits of infra-marginal banks dominate the profit losses of marginal, low-quality banks. These redistributive effects between heterogeneous banks may thus explain why large and productive banks do not generally oppose national capital standards, and in some cases even actively advocate them.

We emphasize, however, that Proposition 1 is a local result, which holds only for the introduction of small capital adequacy ratios. We now look at the properties of our model when capital standards are optimally and non-cooperatively chosen in each of the two symmetric countries. As a preparatory step, we show that when the capital requirement $k_{i}$ is continuously increased, $\kappa$ will fall. Differentiating $\kappa$ in (21) with respect to $k_{i}$ and using $\phi=6 b y_{i} /\left[(1-\hat{q})^{2}(2+\hat{q})\right]$ from (6) and (7) gives:

$$
\frac{d \kappa}{d k_{i}}=\varepsilon \frac{\partial \hat{q}_{i}}{\partial k_{i}}-\frac{6 b[3(\rho-1)(1+\hat{q})+(1+2 \hat{q})(1-\hat{q})]}{(1-\hat{q})^{2}(2+\hat{q})} \frac{\partial y_{i}}{\partial k_{i}},
$$

where

$\varepsilon=\frac{-9 \rho c}{\left(2+\hat{q}^{2}\right)}-\frac{6 b y}{(1-\hat{q})^{2}(2+\hat{q})^{2}}\left\{3(\rho-1)\left[5(1+\hat{q})+2 \hat{q}^{2}\right]+(1-\hat{q})\left(5+2 \hat{q}+2 \hat{q}^{2}\right)\right\}<0$.

From the positive effect of $k_{i}$ on $\hat{q}_{i}$ in (15) we see that the first term in (24) is unambiguously negative. Moreover, the second term in (24) is also negative when $\kappa>0$ initially and hence $d y_{i} / d k_{i}>0$ [see eq. (17)]. Therefore, as long as the value of $\kappa$ is non-negative, $\kappa$ must be unambiguously falling in $k_{i}$.

We assume in the following that an interior optimum in capital standards exists in our model. Hence $W_{i}$ is a concave function in $k_{i}$ where the optimized level $k_{i}^{*}$ is implicitly characterized by the first-order condition

$$
\frac{\partial W_{i}}{\partial k_{i}}=\alpha \frac{\partial \Pi_{i}}{\partial k_{i}}+\beta \frac{\partial T_{i}}{\partial k_{i}}+\frac{\gamma}{2} \frac{\partial S}{\partial k_{i}}=0 .
$$


To determine the sign of $\kappa$ in such an interior optimum, we start by setting $\kappa=0$. From (22c) and (17) the last term in (25) will then be zero, whereas the first two terms will be unambiguously positive from (22a) and (22b), together with (15) and (17). But this implies, from the concavity of $W_{i}\left(k_{i}\right)$, that $k_{i}$ must be further raised towards its optimal level. From (24) this implies in turn that $\kappa$ has to fall from its initial level of zero. Hence in a non-cooperative, interior optimum in capital standards, the value of $\kappa$ must be negative. From (15)-(18) we can then immediately state:

Proposition 2 In a symmetric Nash equilibrium where capital standards are at an interior optimum, $0<k_{i}^{*}<1 \forall i \in\{1,2\}$, a marginal increase in the capital standard of country $i$ has the following effects: $(i)$ it raises the critical quality of active banks in country $i$ and reduces the aggregate loan supply of banks in country $i$; $(i i)$ it reduces the critical quality of active banks in the neighboring country $j$ and raises the aggregate loan supply of banks in $j$; (iii) it reduces total loan supply and aggregate output.

Proposition 2 implies that, in the non-cooperative policy optimum, the cost effect of capital standards must dominate the selection effect. From the effects summarized in the proposition, we can then immediately infer from (22b) that an increase in capital standards will increase tax revenues (i.e., reduce taxpayer losses) in country $i$. Moreover, from $(22 \mathrm{c})$, the increase in $k_{i}$ will reduce the consumer surplus in both countries. The effect on the aggregate profits in the banking sector of country $i$ is ambiguous, in general, and its sign will depend on the sum of the terms $\partial T_{i} / \partial k_{i}$ and $\left(\partial S / \partial k_{i}\right) / 2$. If this sum is positive, then aggregate banking sector profits $\Pi_{i}$ will fall in response to a small increase in $k_{i}$, starting from the non-cooperative equilibrium. In general, this will be the case when the welfare weight on tax revenue $(\beta)$ is sufficiently large, relative to the welfare weight on consumer surplus $(\gamma)$. More specifically, we show in Appendix A.3 that a sufficient condition for the sum of the tax revenue and consumer surplus terms in (25) to be positive is

$$
\beta \frac{2 b}{3(2 \rho-1)} \geq \gamma
$$

To give an example, if $b=3$ and $\rho=1.5$, then any $\beta \geq \gamma$ will ensure that $\partial T_{i} / \partial k_{i}+$ $\left(\partial S_{i} / \partial k_{i}\right) / 2>0$. It then follows from the first-order condition (25) that the marginal effect of $k_{i}$ on the aggregate profits of country $i$ 's banking sector is negative in the non-cooperative regulatory equilibrium. 


\section{Are decentralized capital standards set too low?}

We now turn to analyzing the efficiency of decentralized regulation policies. Since countries are symmetric in our benchmark model, we can simply define regional welfare as the sum of national welfare levels

$$
W_{W}=W_{i}+W_{j} \quad \forall i, j \in\{1,2\}, i \neq j,
$$

where $W_{i}$ is given in eq. (11). Choosing $k_{i}$ so as to maximize aggregate welfare, eq. (27) would imply $\partial W_{W} / \partial k_{i}=0$. The nationally optimal capital standards derived in the previous section are instead chosen so that $\partial W_{i} / \partial k_{i}=0$. Hence, any divergence between nationally and globally optimal capital requirements is shown by the effect of country $i$ 's policy variable $k_{i}$ on the welfare of country $j$. If $\partial W_{j} / \partial k_{i}>0$, then the capital requirements chosen at the national level are 'too lax' from a regional welfare perspective, as an increase in $k_{i}$ would generate a positive externality on the welfare of country $i$. The reverse holds if $\partial W_{j} / \partial k_{i}<0$. In this case the externality on the foreign country is negative and nationally chosen capital requirements are 'too strict' from a regional welfare perspective.

Differentiating $W_{j}$ with respect to $k_{i}$ gives (see Appendix A.4):

$$
\begin{aligned}
\frac{\partial W_{j}}{\partial k_{i}} & =\alpha \frac{\partial \Pi_{j}}{\partial k_{i}}+\beta \frac{\partial T_{j}}{\partial k_{i}}+\frac{\gamma}{2} \frac{\partial S}{\partial k_{i}} \\
& =\frac{-\kappa y_{j}(1-\hat{q})}{2 \Omega(\phi+\hat{q} \tilde{c})}\left\{(\alpha-\gamma) \phi-\gamma \hat{q} \tilde{c}-\frac{\beta\left(1-k_{j}\right)\left(2+5 \hat{q}+2 \hat{q}^{2}\right)}{(2+\hat{q})^{2}}\right\} .
\end{aligned}
$$

There are three terms in the squared bracket of (28). Note that the common multiplier for all these terms is positive because the effects must be evaluated at a negative value of $\kappa$ in the non-cooperative Nash equilibrium (Proposition 2).

The first term in the squared bracket nets out the changes that the isolated cost effect of higher capital standard in country $i$ has on the aggregate profits of country $j$ 's banks on the one hand, and on consumer surplus for the residents of country $j$ on the other. Importantly, if bank profits and consumer surplus are weighed equally in the welfare function of country $j$ (i.e., if $\alpha=\gamma$ ), then the sum of these effects is exactly zero. To explain why these two externalities just offset each other, note from the zero profit condition of firms in (8) that, for given cutoff qualities $\hat{q}_{i}$ and $\hat{q}_{j}$, the increase in the consumer price $P$ induced by the fall in the aggregate loan supply just equals the induced change in the loan rate earned by country $j$ 's banks. Since the initial 
equilibrium is symmetric, with both countries sharing equally in both the supply of loans and the consumption of output, the loss in consumer surplus for country $j$ 's residents is exactly equal to the rise in the profits of country $j$ 's banking sector.

The second effect in (28) is unambiguously negative. This effect arises from the isolated selection effect of capital standards in our model. The higher average loan quality in country $i$ and the reduced average quality in country $j$ reduce total output, on net, and this has a negative effect on consumer surplus in country $j$. At the same time, the higher cutoff quality of banks in country $i$ raises the loan rate in country $i$, but not in country $j$. Therefore, banks in country $j$ do not benefit from the part of the aggregate output reduction that is induced by the changes in the cutoff qualities of loans. On net, therefore, only the negative effect on consumer surplus remains for country $j$.

Finally, the third effect in (28) is also unambiguously negative. This effect gives the change in expected tax subsidies that taxpayers in country $j$ have to pay for their failing banks. Clearly these tax subsidies must increase, because the aggregate size of bank loans rises in country $j$ and the average failure probability also rises, due to the lower cutoff quality of country $j$ 's banking sector (see Proposition 2). Summing up this discussion, we can state our main result:

Proposition 3 When governments weigh the surplus of banks and consumers equally $(\alpha=\gamma)$, then non-cooperatively set capital standards exceed those that maximize aggregate welfare in the union and a 'race to the top' in capital standards occurs. This 'race to the top' is more pronounced, if $(i)$ the valuation of taxpayers' losses in the government objective function is large ( $\beta$ is high), and (ii) if the 'selection effect' of capital standards is strong (c is large).

Proposition 3 is in direct contrast to the results in the existing literature, which have found that the non-cooperative setting of capital standards leads to a 'race to the bottom', or to a 'competition of laxity' (see Sinn, 2003; Acharya, 2003; Dell' Ariccia and Marquez, 2006). Effectively, these contributions have focused on the effect that capital requirements have on the profits of national banking sectors. Our model adds two main effects to these analyses. First, we incorporate a selection effect of capital standards which occurs when banks are heterogeneous and individual bank quality is not observable for firms that require funds. In such a setting, capital standards can partly solve the information problem and redistribute profits from low-quality to high-quality banks within a national banking sector. At the same time, the cost 
disadvantage that higher capital requirements imply for a country's banking sector is reduced, on average, in comparison to models where such selection effects do not arise. As a consequence, models with homogeneous banks will typically overestimate the positive externalities that higher capital requirements in one country have on the profits of the banking sector in the neighboring jurisdiction.

Our second addition is that we incorporate firms that use bank loans to produce final output and we explicitly calculate the costs of bank failures. This allows us to consider more general objective functions where governments set capital standards also with a view on taxpayers and consumers. As we have shown, this leads to additional externalities of capital standards that are negative for the neighboring country. Higher capital standards can be used to shift risks from domestic to foreign banks and thus, via the deposit insurance fund, from domestic to foreign taxpayers. Moreover, higher capital standards negatively affect foreign consumers when loan markets are integrated. In sum, these effects will often overcompensate the positive externality on the foreign banks' profits on which the existing literature has focused.

The effects of capital standards on taxpayers incorporated in our model play an important role for national capital adequacy policies in practice. Thus the Board of Governors of the Federal Reserve System of the United States (2014) clearly points out that the protection of national taxpayers is one of the prime motivations for imposing a supplementary leverage ratio on the largest U.S. banks: "Higher capital standards for these institutions place additional private capital at risk before the federal deposit insurance and the federal government's resolution mechanism would be called upon, and reduce the likelihood of economic disruptions caused by problems at these institutions."

At the same time, our model has shown that capital standards imposed by one country will partly shift taxpayer risks abroad, in particular when the market for bank loans is integrated. This is explicitly emphasized in the European Commission's explanatory memorandum motivating why EU member states are not permitted to set national capital standards above the internationally coordinated Basel III standards: "Inappropriate and uncoordinated stricter requirements in individual Member States might result in shifting the underlying exposures and risks (...) from one EU Member State to another" (European Commission, 2011, p. 10). The results of our model lend support to the policy of the European Union to fully harmonize national capital standards at the level of the Basel III agreement. 


\section{Extensions}

In this section we analyze three extensions of our benchmark model. We first consider which additional effects that arise when banks in each country are partly owned by residents of the other country. Secondly, we consider various asymmetries between countries and numerically derive the resulting non-cooperative equilibria. In the final extension we allow banks to (imperfectly) signal their loan quality to borrowing firms.

\subsection{Foreign ownership of banks}

It is straightforward to extend our analysis to the case where residents in each country own a fraction of the banks in the neighboring country and hence participate in the profits of the foreign banking sector. International cross-ownership of banks is an empirically important phenomenon. ${ }^{21}$ To maintain symmetry, let residents of each country own a share $\sigma$ of its own resident banks and a share $(1-\sigma)$ of the foreign banks. The welfare function of country $j$ then changes to $W_{j}=\alpha\left[\sigma \Pi_{j}+(1-\sigma) \Pi_{i}\right]+\beta T_{j}+\gamma S / 2$. Differentiation with respect to $k_{i}$ yields

$$
\frac{\partial W_{j}}{\partial k_{i}}=\alpha \sigma \frac{\partial \Pi_{j}}{\partial k_{i}}+\alpha(1-\sigma) \frac{\partial \Pi_{i}}{\partial k_{i}}+\beta \frac{\partial T_{j}}{\partial k_{i}}+\frac{\gamma}{2} \frac{\partial S}{\partial k_{i}} .
$$

In comparison to the previous section [eq. (28)], two changes occur in the analysis of $d W_{j} / d k_{i}$. First, the positive effect of $k_{i}$ on the profits of the banking sector in country $j$, $\Pi_{j}$, is now weighed with a factor $\sigma<1$ and is thus diminished. Secondly, through their partial ownership of banks in country $i$, residents of country $j$ are now also affected by changes in the banking sector profits of country $i$. If condition (26) is met, then aggregate banking sector profits in country $i$ fall following an increase in $k_{i}$, leading to an additional negative externality for the residents of country $j$. In this case, the net externalities on the foreign country added by foreign ownership of banks are thus unambiguously negative. Under the conditions of Proposition 3, which imply that noncooperatively set capital standards are above their globally efficient levels even in the absence of foreign ownership, we can summarize:

\footnotetext{
${ }^{21}$ To give two examples, foreigners held $43 \%$ of the shares of the largest commercial bank in Germany, the Deutsche Bank, in 2014 (www.db.com/ir/de/content/673.htm). The share ownership of the French bank BNP Paribas included 25.8\% non-European institutional investors in 2015, and $11 \%$ were held by state funds from Belgium and Luxembourg (https://invest.bnpparibas.com/en/share-ownership).
} 
Proposition 4 When governments weigh the surplus of banks and consumers equally $(\alpha=\gamma)$ and the weight on tax revenue is sufficiently large, relative to the weight on consumer surplus [condition (26) holds], then foreign ownership of banks magnifies the negative net externality of capital standards on the foreign country's welfare and intensifies the 'race to the top'.

\subsection{Asymmetries between countries}

As a second extension of our model, we introduce two different types of asymmetries between the two countries. We first assume that country 1 has a higher welfare weight $(\beta)$ of tax revenues than country 2 . This could arise, for example, because country 1 has a larger size of the banking sector, relative to its GDP, and is therefore more concerned about the risks to its public finances as a result of failing banks. This setting could, for example, describe the situation in Switzerland. The model is too complicated to be solved analytically when there are asymmetries between countries. We therefore use numerical solution methods and summarize our results in part $A$ of Table 1.

Table $1 A$. shows the intuitive result that country 1 , which has the higher valuation of tax revenues (the 'high-beta' country), will have the higher capital standard in the non-cooperative equilibrium. As a consequence, the cutoff quality level of banks, $\hat{q}$, is higher in country 1 than in country 2 [cf. eq. (5)]. The aggregate loan volume and aggregate profits fall in country 1 , as the higher cost of capital dominates the increase in the loan rate. However, expected losses to taxpayers fall sharply due to both the lower loan supply and the lower risk exposure of taxpayers in country 1 . The reduction in the loan supply originating from banks in country 1 raises the loan rate in country 2 and draws some additional banks in this country into the market ( $\hat{q}_{2}$ falls). Accordingly, the total loan volume and aggregate bank profits rise in country 2. Finally, the higher loan volume and the lower average quality of resident banks imply higher expected losses to taxpayers in country 2 .

A second asymmetry is to introduce different costs of equity, $\rho_{i}$, in the two countries. Such differences can arise, for example, when there are differences in the quality of the regulatory framework across countries (see Morrison and White, 2009) and investors in better regulated countries demand lower risk premia. Another reason for differences in the costs of equity could be differential dividend taxes. Investors in the country with the higher dividend tax would then demand a higher (gross) return on their equity, $\rho_{i}$. The 
Table 1: Numerical results for asymmetric countries

\begin{tabular}{|c|c|c|c|c|c|c|c|c|c|c|}
\hline & $k_{1}$ & $k_{2}$ & $\hat{q}_{1}$ & $\hat{q}_{2}$ & $L_{1}$ & $L_{2}$ & $\Pi_{1}$ & $\Pi_{2}$ & $T_{1}$ & $T_{2}$ \\
\hline \multicolumn{11}{|c|}{ A. Different welfare weights of tax revenue $\left(\beta_{i}\right)$} \\
\hline$\beta_{1}=1.0$ & 0.335 & 0.335 & 0.306 & 0.306 & 2.110 & 2.110 & 1.068 & 1.068 & -0.325 & -0.325 \\
\hline$\beta_{1}=1.5$ & 0.437 & 0.336 & 0.362 & 0.303 & 1.971 & 2.158 & 1.014 & 1.113 & -0.236 & -0.333 \\
\hline$\beta_{1}=2.0$ & 0.531 & 0.337 & 0.406 & 0.300 & 1.847 & 2.207 & 0.957 & 1.159 & -0.172 & -0.342 \\
\hline \multicolumn{11}{|c|}{ B. Different costs of equity $\left(\rho_{i}\right)$} \\
\hline$\rho_{1}=2.00$ & 0.335 & 0.335 & 0.306 & 0.306 & 2.110 & 2.110 & 1.068 & 1.068 & -0.325 & -0.325 \\
\hline$\rho_{1}=1.75$ & 0.439 & 0.334 & 0.330 & 0.306 & 2.094 & 2.106 & 1.090 & 1.065 & -0.262 & -0.324 \\
\hline$\rho_{1}=1.50$ & 0.627 & 0.334 & 0.365 & 0.306 & 2.072 & 2.101 & 1.128 & 1.061 & -0.164 & -0.324 \\
\hline
\end{tabular}

Note: Parameter values held constant: $A=10, \alpha=\gamma=1.0, \beta_{2}=1.0, \rho_{2}=2.0$.

results for the case where country 1 has the lower cost of equity are shown in part $B$ of Table 1. A lower cost of equity makes it less costly for the government of country 1 to raise its capital standard, and $k_{1}$ will accordingly rise in the non-cooperative policy equilibrium. Hence, in our setting the better regulated country - as measured by a lower level of $\rho_{i}$-will also have the higher capital standard, contrary to the results of Morrison and White (2009).

The higher capital requirement drives some banks in country 1 to exit the market, despite the reduction in their cost of equity. With respect to the aggregate loan supply and aggregate profits in country 1, the effects of higher capital standards and lower costs of equity are mutually offsetting. As a result, the equilibrium changes in these variables are small. Taxpayer losses are clearly reduced in equilibrium, however, due to the higher equity ratio and the resulting reduction in the risk exposure of taxpayers. Finally, the repercussions on country 2 are small in this setting, due to the small changes in the aggregate loan volume of country 1.

\subsection{Quality signalling by banks}

We now extend our basic model by assuming that banks are able to (imperfectly) signal their quality. ${ }^{22}$ In particular, high-quality banks are willing to invest in the costly signal of holding equity above the minimum standard, in order to signal their high quality

\footnotetext{
${ }^{22}$ We are particularly indebted to Alan Morrison and Klaus Schmidt for their helpful suggestions on the modelling strategy in this extension.
} 
to borrowers. This signal will lead entrepreneurs to pay a higher loan rate to banks that hold a higher amount of equity than is mandated by the capital requirement of the bank's country of residence. Given the complexity of bank balance sheets and the potential costs of screening, it seems hard to imagine, however, that even the smallest differences in the capital holding of banks can be observed and understood by each entrepreneur. Therefore, and to keep the model tractable, we confine our analysis in this section to the case where banks can choose one specific, 'high' level of equity $k_{i}^{h} \equiv k_{i}+\tilde{k}_{i}$, which exceeds the minimum capital requirement $k_{i}$ by the amount $\tilde{k}_{i}$.

The isolated effect of changing the funding structure towards more equity is obtained by differentiating the banks' optimized profits in eq. (4) with respect to $\tilde{k}_{i}$. This gives

$$
\frac{\partial \pi_{i}^{*}(q)}{\partial \tilde{k}_{i}}=\frac{q \phi-\tilde{k}_{i} \rho}{b}(q-\rho)<0 .
$$

Holding more equity unambiguously reduces the profits of all banks, because equity is (weakly) more expensive for banks than savings deposits are, and because the share of bank funds that is covered by deposit insurance declines. Importantly, however, eq. (30) shows that the cost of raising equity above the minimum standard is higher for low quality banks, because these banks benefit most from the existence of the deposit insurance system. This implies that holding equity above the required level is indeed a signal of quality, as such a signal can only be profitable for high quality banks.

Indexing the banks' quality pools by $p \in\{h, l\}$, all banks that choose to hold the high equity level $k_{i}^{h}$ will then be identified as being in the high quality pool $(p=h)$, whereas all banks that hold only the minimum amount of equity $k_{i}$ are classified as belonging to the low quality pool $(p=l)$. The quality of the bank that is indifferent between belonging to the high quality pool and the low quality pool is denoted by $\tilde{q}$. From eqs. (3)-(4), this critical quality level is determined by the condition that the additional loan revenue from opting into the high quality pool equals the additional financing costs:

$$
\tilde{q}_{i}\left(R_{i}^{h}-R_{i}^{l}\right)=\left(k_{i}^{h}-k_{i}\right)\left(\rho-\tilde{q}_{i}\right)
$$

Here

$$
R_{i}^{h}-R_{i}^{l}=c\left[\frac{1}{q^{e l}}-\frac{1}{q^{e h}}\right]
$$

gives the difference in loan rates paid by entrepreneurs to banks of the different quality pools $h$ and $l$ in the same country $i$ and

$$
q_{i}^{e h}=\frac{(2+\tilde{q}) l_{1}+(2 \tilde{q}+1) l_{\tilde{q}}}{3\left(l_{1}+l_{\tilde{q}}\right)}, \quad q_{i}^{e l}=\frac{2 \tilde{q}+\hat{q}}{3}
$$


Table 2: Numerical results for quality signalling by banks

\begin{tabular}{|c|c|c|c|c|c|c|c|c|c|}
\hline & $\hat{q}_{i}$ & $\tilde{q}_{i}$ & $R_{i}^{h}-R_{i}^{l}$ & $y_{i}^{l}$ & $y_{i}^{h}$ & $y_{i}$ & $\Pi_{i}$ & $T_{i}$ & $W_{i}$ \\
\hline \multicolumn{10}{|c|}{ A. low fixed cost of firms $(c=0.50)$} \\
\hline$k_{i}=0.00$ & 0.000 & 0.961 & 0.270 & 1.814 & 0.230 & 2.044 & 6.270 & -1.018 & 9.330 \\
\hline$k_{i}=0.10$ & 0.020 & 0.922 & 0.285 & .578 & 0.446 & 2.023 & 6.144 & -0.868 & .283 \\
\hline$k_{i}=0$ & 0.028 & 0.901 & 0.294 & 1.464 & 0.551 & 2.015 & 6.092 & -0.807 & .262 \\
\hline \multicolumn{10}{|c|}{$B$. high fixed cost of firms $(c=0.75)$} \\
\hline$n_{i}-0.00$ & .000 & 0.633 & 0.879 & 0.456 & 1.451 & 1.908 & 5.467 & -0.655 & 8.386 \\
\hline$k_{i}=0.10$ & 0.033 & 0.299 & 2.544 & 0.029 & 1.818 & 1.847 & 5.180 & -0.163 & 8.411 \\
\hline$k_{i}=0.14$ & 0.052 & 0.248 & 3.063 & 0.012 & 1.830 & 1.841 & 5.165 & -0.115 & 8.430 \\
\hline
\end{tabular}

Note: Parameter values held constant: $A=10, \rho=1.25, \alpha=\gamma=1.0, \beta=1.1, k_{i}^{h}=0.9$.

are the expected probabilities of a successful loan in the high quality and in the low quality banking pool, respectively.

Entrepreneurs are able to identify the critical quality level $\tilde{q}_{i}$ at which a bank is just indifferent between being in the high versus the low quality pool [eq. (31)]. Given this benchmark, entrepreneurs infer that all banks with quality $q<\tilde{q}_{i}$ will prefer to hold only the minimum amount of capital $k_{i}$ and be identified as a low quality bank, whereas all banks with $q>\tilde{q}_{i}$ will choose to signal that they belong to the high quality pool and set $k_{i}^{h}$. The expected quality of each pool [eq. (33)] can then be calculated as the weighted average of the number of loans issued by the lowest quality bank and the highest quality bank within each pool. ${ }^{23}$

Again, the mechanisms of this extended model are best described by means of numerical analyses. The level of the fixed cost parameter of firms, $c$, is critical for the results of this extension. We differentiate case $A$, where the fixed cost parameter is relatively low $(c=0.50)$, and case $B$, where it is relatively high $(c=0.75)$. In each case, we analyze a coordinated increase in the minimum capital requirements for banks, $k_{i}$. The results of the numerical analyses are summarized in Table 2. The analytical expressions for output levels, aggregate bank profits and (negative) tax revenues in this two-tier model are given in Appendix A.5.

In case $A$, the fixed cost of firms are low, implying from (32) that the difference in

\footnotetext{
${ }^{23}$ To arrive at eq. (33), we substitute eq. (2) in $q^{e p}=\frac{Y^{p}}{L^{p}}=\int_{\underline{q}^{p}}^{\bar{q}^{p}} q l(q) d q / \int_{\underline{q}^{p}}^{\bar{q}^{p}} l(q) d q$, solve the integrals, and set the pool-specific lower bounds at $\underline{q}^{l}=\hat{q}, \underline{q}^{h}=\tilde{q}$ and upper bounds at $\bar{q}^{l}=\tilde{q}, \bar{q}^{h}=1$.
} 
loan rates $R_{i}^{h}-R_{i}^{l}$ is small in equilibrium. Eq. (31) then implies a relatively large value of $\tilde{q}_{i}$ for any given extra cost of signalling $\left(k_{i}^{h}-k_{i}\right)(\rho-\tilde{q})$. Hence in this case a relatively large share of banks remains in the low quality pool. Coordinated increases in the minimum capital ratio $k_{i}$ raise $\hat{q}_{i}$ above zero, implying that the weakest banks in each country exit the market. A coordinated increase in $k_{i}$ also reduces the extra cost of signalling the high quality level $k_{i}^{h}$ [the right-hand side of (31)], and thus tends to reduce the quality level of the cutoff bank $\tilde{q}_{i}$ [on the left-hand side of (31)]. Moreover, from (33), a fall in $\tilde{q}_{i}$ reduces $q_{i}^{e l}$ by more than $q_{i}^{e h}$, raising the extra loan revenue from being in the high quality pool, $R_{i}^{h}-R_{i}^{l}$. This effect will further reduce $\tilde{q}_{i}$ in equilibrium. With a low cost parameter $c$ the last effect is moderate, however, and the equilibrium change in $\tilde{q}_{i}$ is therefore also moderate. As a result, bank profits, total output and expected losses to taxpayers will all be moderately reduced by a coordinated increase in $k_{i}$. When losses to taxpayers are valued only slightly more than bank profits and consumer surplus $(\alpha=\gamma=1.0 ; \beta=1.1)$, the net effect on welfare will be negative in both countries. Hence in this case the optimal coordinated capital requirement is zero. In case $B$, the fixed cost of firms $c$ are high and so is the added loan revenue in the high quality pool, $R_{i}^{h}-R_{i}^{l}$. Since the extra financing costs of being in the high quality pool are the same as in case $A$, eq. (31) implies that the quality of the cutoff bank $\tilde{q}_{i}$ is now lower. Hence most loans are now provided by banks in the high-quality pool. An increase in the minimum capital requirement again drives the weakest banks from the market, and the rise in $\hat{q}_{i}$ is stronger now, due to the lower absolute value of loan rates [see eq. (9)]. Also, the higher minimum capital requirement $k_{i}$ again reduces the extra costs of signalling to enter the high quality pool, reducing $\tilde{q}_{i}$ in equilibrium. The additional loan revenue from being in the high quality pool, $R_{i}^{h}-R_{i}^{l}$, will now increase by more than in case $A$, due to the higher cost multiplier $c$ [eq. (32)]. Hence, in equilibrium, the cutoff quality $\tilde{q}_{i}$ falls more strongly than in case $A$, implying that capital requirements now reduce the expected losses to taxpayers more effectively. A welfare function giving a slightly higher weight to taxpayers $(\beta=1.1)$ than to bank profits and consumer surplus $(\alpha=\gamma=1.0)$ is then sufficient for a positive overall welfare effect of capital requirements. Hence, in this case the optimal coordinated capital requirement eliminates all lending by banks in the low quality pool $\left(k_{i} \approx 0.14\right)$.

To summarize, the extension analyzed in this subsection has introduced self-selection of banks, which can opt either into a high quality pool, financing their loans with a high equity share $k_{i}^{h}$, or into the low quality pool where the minimum capital requirement $k_{i}$ 
is binding. Changes in the minimum capital requirement $k_{i}$ then affect the selection of heterogeneous banks in two ways. First, as in the benchmark model, an increase in the minimum capital ratio raises the critical quality for market entry, $\hat{q}_{i}$, leading the weakest banks to exit the market and improving the overall pool quality of the remaining banks. A second and new effect is that a higher minimum capital requirement also changes the cutoff quality $\tilde{q}_{i}$ above which banks self-select into the high quality pool. By increasing the financing costs in the low quality pool, but not in the high quality pool, opting into the high quality pool becomes attractive for a larger set of banks and $\tilde{q}_{i}$ accordingly falls. The effects of stricter minimum capital ratios $k_{i}$ on the critical quality levels $\hat{q}_{i}$ and $\tilde{q}_{o}$ are both stronger, in equilibrium, the higher is the valuation of quality by producing firms, as measured by their fixed production cost $c$.

\section{Conclusions}

We have studied international competition in capital standards in a setting where banks differ exogenously in the quality of their monitoring, and hence in the likelihood that their loans will succeed. In this setting national capital standards act as a positive signal for the pool quality of banks in the country that introduces the regulation, and imply higher financing costs but also higher loan rates for the resident banks in equilibrium. Our model also incorporates a production sector that uses bank loans to produce output in an integrated market, and national savings insurance schemes that fully insure depositors against bank failures. Capital standards shift taxpayer risks from the more regulated to the less regulated country and they also reduce consumer surplus in the integrated market by lowering the overall availability of credit. These negative externalities on the foreign country imply that the non-cooperative setting of capital standards leads to a 'race to the top' when governments weigh consumer surplus at least as high as bank profits, in direct contrast to the 'race to the bottom' on which the existing literature has focused.

Our model can thus explain why countries such as Switzerland or the United States, which are characterized by large banking sectors and accordingly a high risk exposure of national taxpayers, resort to capital adequacy rules that exceed internationally coordinated standards such as the Basel III agreement. At the same time, our model offers a motivation for why the European Union has insisted on a strict harmonization of the national capital standards in its member states, at the levels agreed upon in the Basel 
III accord. The consumer surplus externality that arises from capital standards in our model provides an argument for why the setting of an upper bound on national capital standards is especially relevant in an integrated market like the EU. Our model results indicate, however, that the coordinated setting of upper limits on capital standards may also be a relevant coordination measure in a global context.

Our model can be extended in several ways. A first relevant extension is to introduce an endogenous monitoring decision of banks while maintaining heterogeneity in the monitoring costs. This would allow, for example, to introduce higher monitoring costs

for loans to foreign firms and thus incorporate a 'home bias' in the lending decisions of banks that is observable in the data (e.g. Niepmann, 2013). Another relevant extension would be to endogenize the degree to which governments provide insurance for savings deposits. Such a setting would also permit an analysis of how the introduction of a supranational deposit insurance scheme - as is currently being debated as the final pillar of the European banking union - interacts with the harmonization of capital adequacy standards. We leave these and other extensions for future work.

\section{Appendix}

\section{A.1 Derivation of eqs. (15)-(18)}

To analyze the effects of an increase in $k_{i}$ on aggregate output and the cutoff qualities $\hat{q}_{i}$ in the two countries, we totally differentiate the equation system (10a)-(10c) to get

$$
\begin{gathered}
{\left[A-y-1+k_{i}-2 \tilde{c}\right] d \hat{q}_{i}=\hat{q}_{i} d y+\left(\rho-\hat{q}_{i}\right) d k_{i},} \\
{\left[A-y-1+k_{j}-2 \tilde{c}\right] d \hat{q}_{j}=\hat{q}_{j} d y} \\
d y=\frac{3\left(1-\hat{q}^{3}\right) c}{\left[3 b+2\left(1-\hat{q}^{3}\right)\right](2+\hat{q})^{2}}\left(d \hat{q}_{i}+d \hat{q}_{j}\right)-\frac{\left[3 \rho\left(1-\hat{q}^{2}\right)-2\left(1-\hat{q}^{3}\right)\right]}{6 b+4\left(1-\hat{q}^{3}\right)}\left(d k_{i}+d k_{j}\right),
\end{gathered}
$$

where we have used the short-hand notations (3) and (20) from the main text, eq. (5) has been used to simplify terms, and (A.3) has used symmetry after differentiation.

This equation system can be simplified by substituting (A.3) into (A.1) and (A.2). This yields the two-equation system

$$
\begin{aligned}
& \left\{(\hat{q} \tilde{c}+\phi)\left[6 b+4\left(1-\hat{q}^{3}\right)\right]-2 \hat{q}\left(1-\hat{q}^{3}\right) \tilde{c}\right\} d q_{i}=2 \hat{q} \tilde{c}\left(1-\hat{q}^{3}\right) d q_{j} \\
& \quad+\left\{(\rho-\hat{q})\left[6 b+4\left(1-\hat{q}^{3}\right)\right]-\left[3 \rho \hat{q}\left(1-\hat{q}^{2}\right)-2 \hat{q}\left(1-\hat{q}^{3}\right)\right]\right\} d k_{i}
\end{aligned}
$$




$$
\begin{array}{r}
\left\{(\hat{q} \tilde{c}+\phi)\left[6 b+4\left(1-\hat{q}^{3}\right)\right]-2 \hat{q}\left(1-\hat{q}^{3}\right) \tilde{c}\right\} d q_{j} \\
=2 \hat{q} \tilde{c}\left(1-\hat{q}^{3}\right) d q_{i}-\hat{q}\left[3 \rho \hat{q}\left(1-\hat{q}^{2}\right)-2 \hat{q}\left(1-\hat{q}^{3}\right)\right] d k_{i}
\end{array}
$$

Solving the system (A.4) and (A.5) gives equations (15) and (16) in the main text. Substituting these results back into (A.3) yields

$$
\frac{\partial y}{\partial k_{i}}=\frac{(1-\hat{q}) \kappa}{2 \phi \Omega},
$$

where $\kappa$ and $\Omega$ are given in (21) and (19). Finally, differentiating (7) gives

$$
d y_{i}=\frac{1}{6 b}\left\{-2\left(1-\hat{q}_{i}^{3}\right) d y+2\left(1-\hat{q}_{i}^{3}\right) \tilde{c} d \hat{q}_{i}-\left[3 \rho\left(1-\hat{q}_{i}^{2}\right)-2\left(1-\hat{q}_{i}^{3}\right)\right] d k_{i}\right\}
$$

Substituting (15) and (16) along with (A.6) into (A.7) gives (17) and (18) in the main text.

\section{A.2 Derivation of conditions (23a)-(23b)}

From (22a) and (22c) and using (17), a positive effect of capital standards on bank profits and consumer surplus, evaluated at $k=0$ initially, requires that $\kappa>0$ in (21). Evaluating $\kappa$ at $k=0$ and noting that $\hat{q}=0$ for $k=0$ from (5), this condition is

$$
\left.\kappa\right|_{k=0}=\frac{3 \rho c}{2}-\left(R_{i}-1\right)(3 \rho-2)>0 .
$$

The endogenous variable $\left(R_{i}-1\right)$ can be substituted using (9) together with (6) and (7). This yields

$$
R_{i}-\left.1\right|_{k=0}=\frac{3 b}{2(3 b+2)}(2 A-3 c-2) .
$$

Substituting (A.9) in (A.8), a sufficient condition for $\left.\kappa\right|_{k=0}>0$ is

$$
\frac{3}{2} \rho c-(3 \rho-2)\left[A-\frac{3 c}{2}-1\right]>0 .
$$

Collecting the terms for $c$ gives condition (23a) in the main text.

A positive effect on taxpayers will result when the positive first two effects in (22b) dominate the third effect, which is negative for $\kappa>0$. Substituting in from (15) and (17), evaluating at $k=\hat{q}=0$ and using $\left.y\right|_{k=0}=\left(R_{i}-1\right) / 3 b$ from (6) and (7) gives

$$
\left.\frac{\partial T_{i}}{\partial k_{i}}\right|_{k=0}=\frac{\left(R_{i}-1\right)}{6 b}+\frac{3 \rho}{12 b}-\frac{\kappa}{12 b \phi}>0 .
$$


Ignoring the positive first term and noting that $\left.\phi\right|_{k=0}=\left.\left(R_{i}-1\right)\right|_{k=0}$ gives, as a sufficient condition

$$
\left.\frac{\partial T_{i}}{\partial k_{i}}\right|_{k=0}>0 \Leftrightarrow 3 \rho\left(R_{i}-1\right)-\kappa>0 .
$$

Using (A.8) and (A.9) yields

$$
\left.\frac{\partial T_{i}}{\partial k_{i}}\right|_{k=0}>0 \Leftrightarrow \frac{12 b(2 A-3 c-2)(3 \rho-1)}{(3 b+2)}>\frac{3 \rho c}{2} .
$$

Noting that $(3 \rho-1) \geq 2 \rho$ and collecting the terms involving $c$ gives $(23 \mathrm{~b})$ as a sufficient condition.

\section{A.3 Derivation of equation (26)}

Since $\kappa$ and thus $\partial y_{i} / \partial k_{i}$ are negative from Proposition 2, all terms in the tax revenue expression (22b) are positive, whereas the consumer surplus term in (22c) is negative. For the sum of these terms to be positive, a sufficient condition is thus that the first term in (22b) dominates the term in (22c). We first simplify $\partial y_{i} / \partial k_{i}$ using (17). An upper bound on this derivative is

$$
\begin{aligned}
-\frac{\partial y_{i}}{\partial k_{i}} & =\frac{(1-\hat{q})\left[6 b(\phi+\tilde{c} \hat{q})+2 \phi\left(1-\hat{q}^{3}\right)\right] \kappa}{12 b(\phi+\tilde{c} \hat{q})\left[3 b(\phi+\tilde{c} \hat{q})+2 \phi\left(1-\hat{q}^{3}\right)\right]} \\
& <\frac{(1-\hat{q}) \phi[3(\rho-1)(1+\hat{q})+(1+2 \hat{q})(1-\hat{q})]}{6 b \phi}<\frac{(1-\hat{q})(2 \rho-1)}{2 b} .
\end{aligned}
$$

In the numerator, the first inequality gives an upper bound on the absolute value of $\kappa$ in (21), which is negative, by dropping the second (counteracting) term. The second inequality then gives an upper bound on the size of the first term in $\kappa$.

At the same time we have $\beta /(2+\hat{q}) \geq \beta / 3$. We can then directly compare the first term in $(22 \mathrm{~b})$ with $(22 \mathrm{c})$. This gives the sufficient condition

$$
\beta \frac{(1-\hat{q}) y_{i}}{(2+\hat{q})}>\gamma y_{i} \frac{\partial y_{i}}{\partial k_{i}} \Longleftrightarrow \frac{\beta}{3}>\gamma \frac{(2 \rho-1)}{2 b} .
$$

Rewriting (A.12) gives condition (26) in the main text.

\section{A.4 Derivation of equation (28)}

Using (12)-(14), we can write welfare in country $j$ as

$$
W_{j}=\frac{6 \alpha b y_{j}^{2}}{\left(1-\hat{q}_{j}\right)\left(2+\hat{q}_{j}\right)^{2}}-\frac{\beta\left(1-k_{j}\right)\left(1-\hat{q}_{j}\right) y_{j}}{\left(2+\hat{q}_{j}\right)}+\frac{\gamma\left(y_{i}+y_{j}\right)^{2}}{4} \quad i \neq j .
$$


Differentiating with respect to $k_{i}$ gives, in a first step

$$
\begin{aligned}
\frac{\partial W_{j}}{\partial k_{i}} & =\frac{12 \alpha b y_{j}}{(1-\hat{q})(2+\hat{q})^{2}} \frac{\partial y_{i}}{\partial k_{i}}+\frac{18 \alpha b y_{j}^{2} \hat{q}}{(1-\hat{q})^{2}(2+\hat{q})^{3}} \frac{\partial \hat{q}_{j}}{\partial k_{i}} \\
& -\frac{\beta\left(1-k_{j}\right)(1-\hat{q})}{(2+\hat{q})} \frac{\partial y_{j}}{\partial k_{i}}+\frac{3 \beta\left(1-k_{j}\right) y_{j}}{(2+\hat{q})^{2}} \frac{\partial \hat{q}_{j}}{\partial k_{i}}+\frac{\gamma\left(y_{i}+y_{j}\right)}{2} \frac{\partial y}{\partial k_{i}}
\end{aligned}
$$

Substituting in from (16)-(18), using $\phi_{j}=6 b y_{j} /\left[(1-\hat{q})^{2}(2+\hat{q})\right]$ and collecting terms gives eq. (28) in the main text.

\section{A.5 The extended model with signalling by banks}

Total output with loans from banks in country $i$ is composed of the output produced with bank loans from the low and the high quality pool, $y_{i}=y_{i}^{l}+y_{i}^{h}$. These are

$$
\begin{aligned}
& y_{i}^{l}=\int_{\hat{q}_{i}}^{\tilde{q}_{i}} \frac{q \phi_{i}^{l}-k_{i} \rho}{b} d q=\frac{\tilde{q}_{i}^{3}-\hat{q}_{i}^{3}}{3 b} \phi_{i}^{l}-\frac{\tilde{q}_{i}^{2}-\hat{q}_{i}^{2}}{2 b} k_{i} \rho, \\
& y_{i}^{h}=\int_{\tilde{q}_{i}}^{1} \frac{q \phi_{i}^{h}-k_{i}^{h} \rho}{b} d q=\frac{1-\tilde{q}_{i}^{3}}{3 b} \phi_{i}^{h}-\frac{1-\tilde{q}_{i}^{2}}{2 b} k_{i}^{h} \rho .
\end{aligned}
$$

Analogously, total bank profits in country $i$ are composed of bank profits in the low and the high quality pool

$$
\begin{aligned}
\Pi_{i} & =\Pi_{i}^{l}+\Pi_{i}^{h}=\int_{\hat{q}_{i}}^{\tilde{q}_{i}} \frac{\left(q \phi_{i}^{l}-k_{i} \rho\right)}{2 b} d q+\int_{\tilde{q}_{i}}^{1} \frac{\left(q \phi_{i}^{h}-k_{i}^{h} \rho\right)}{2 b} d q \\
& =\frac{\left(\phi_{i}^{h}-k_{i}^{h} \rho\right)^{3}}{6 b \phi_{i}^{h}}+\frac{\left(\tilde{q}_{i} \phi_{i}^{h}-k_{i}^{h} \rho\right)^{3}}{6 b}\left(\frac{1}{\phi_{i}^{l}}-\frac{1}{\phi_{i}^{h}}\right)
\end{aligned}
$$

where, following integration, the second step has used (5) and (31).

Finally, expected losses to taxpayers can be calculated as

$$
T_{i}=-\left[\left(1-k_{i}\right)\left(1-q_{i}^{e l}\right) \frac{y_{i}^{l}}{q_{i}^{e l}}+\left(1-k_{i}^{h}\right)\left(1-q_{i}^{e h}\right) \frac{y_{i}^{h}}{q_{i}^{e h}}\right],
$$

where $y_{i}^{l}$ and $y_{i}^{h}$ are given in (A.14), $q_{i}^{e l}$ and $q_{i}^{e h}$ are in (33), and loan levels in each quality pool $p \in\{h, l\}$ follow from output levels by $L_{i}^{p}=y_{i}^{p} / q_{i}^{e p}$. 


\section{References}

Acharya, V. (2003). Is the international convergence of capital adequacy regulation desirable? Journal of Finance 58, 2745-2781.

Admati, A., Hellwig, M. (2013). The bankers' new clothes. What's wrong with banking and what to do about it. Princeton University Press.

Akerlof, G.A. (1970). The market for lemons: quality, uncertainty, and the market mechanism. Quarterly Journal of Economics 84, 488-500.

Auerbach, A.J., Devereux, M.P., Simpson, H. (2010). Taxing corporate income. In: J. Mirrlees, S. Adam, T. Besley, R. Blundell, S. Bond, R. Chote, M. Gammie, P. Johnson, G. Myles and J. Poterba (eds), Dimensions of Tax Design: the Mirrlees Review, Oxford University Press, 837-893.

Barth, J., Lee, C., Phumiwasana, T. (2006). Deposit insurance schemes. In: Ch. Lee and A. Lee (eds.), Encyclopedia of Finance, 299-306.

Beck, T., Wagner, W. (2013). Supranational supervision - How much and for whom. CEPR Discussion Paper No. 9546.

Board of Governors of the Federal Reserve System (2014). Agencies adopt enhanced supplementary leverage ratio. Press release from 8 April 2014 (www.federalreserve.gov/newsevents/press/bcreg/20140408a.htm).

Bolton, P., Freixas, X., Gambacorta, L., Mistrulli, P.E. (2013). Relationship and transaction lending in a crisis. NBER Working Paper No. 19467. Cambridge, Mass.

Boot, A., Thakor, A. (2000). Can relationship banking survive competition? Journal of Finance 55, 679-713.

Buch, C., Koch, C.T., Koetter, M. (2011). Size, productivity, and international banking. Journal of International Economics 85, 329-334.

Chor, D., 2009. Subsidies for FDI. Implications from a model with heterogeneous firms. Journal of International Economics 78, 113-125.

Dell'Ariccia, G., Marquez, R. (2006). Competition among regulators and credit market integration. Journal of Financial Economics 79, 401-430. 
Devereux, M., Johannesen, N., Vella, J. (2013). Can taxes tame the banks? Evidence from European bank levies. Oxford University Centre for Business Taxation. Working Paper 13/25.

European Commission (2011). Proposal for a Regulation of the European Parliament and of the Council on prudential requirements for credit institutions and investment firms, Part 1. Document COM(2011) 452 final. Brussels.

Hellman, T., Murdock, K., Stiglitz, J. (2000). Liberalization, moral hazard in banking, and prudential regulation: Are capital requirements enough? American Economic Review 90, 147-165.

Inderst, R. (2013). Prudence as a competitive advantage: On the effects of competition on banks' risk-taking incentives. European Economic Review 60, 127-143.

Ivashina, V., Scharfstein, D. (2010). Bank lending during the financial crisis of 2008. Journal of Financial Economics 97, 319-338.

Keen. M. (2011). Rethinking the taxation of the financial sector. CESifo Economic Studies 5\%, 1-24.

Keen, M., Konrad, K. (2013). The theory of international tax competition and coordination. Handbook of Public Economics, Volume 5, 257-328.

Kopecky, K., VanHoose, D. (2006). Capital regulation, heterogeneous monitoring costs, and aggregate loan quality. Journal of Banking and Finance 30, 2235-2255.

Morrison, A., White, L. (2005). Crises and capital requirements in banking. American Economic Review 95, 1548-1572.

Morrison, A., White, L. (2009). Level playing fields in international financial regulation. Journal of Finance 64, 1099-1142.

Niepmann, F. (2013). Banking across borders with heterogeneous banks. Federal Reserve Bank of New York Staff Report No. 609.

Niepmann, F., Schmidt-Eisenlohr, T. (2013). Bank bailouts, international linkages, and cooperation. American Economic Journal: Economic Policy 5, 270-305.

Repullo, R. (2004). Capital requirements, market power, and risk taking in banking. Journal of Financial Intermediation 13, 156-182. 
Rochet, J.-Ch. (1992). Capital requirements and the behaviour of commercial banks. European Economic Review 36, 1137-1178.

Sinn, H.W. (1997). The selection principle and market failure in systems competition. Journal of Public Economics 66, 247-274.

Sinn, H.W. (2003). Risktaking, limited liability, and the competition of bank regulators. Finanzarchiv 59, 305-329. 